\title{
The role of eclogites in the growth of Archean cratons: a case study from west Africa
}

\author{
Barth, M.G. ${ }^{1}$, Rudnick, R.L. ${ }^{1}$, Spicuzza, M.J. ${ }^{2}$, Valley, J.W. ${ }^{2}$, and Haggerty, S.E. ${ }^{3}$ \\ 1. Department of Earth and Planetary Sciences, Harvard University, Cambridge, MA 02138, USA \\ 2. Department of Geology and Geophysics, University of Wisconsin, Madison, WI 53706, USA \\ 3. Department of Geology, University of Massachusetts, Amherst, MA 01003, USA
}

Eclogites, bi-mineralic rocks composed of garnet and omphacite, are minor but ubiquitous constituents in mantle xenolith suites brought up by kimberlites in Archean cratons. They have been variously interpreted as cumulates from mantle-derived magmas or as fragments of recycled oceanic crust. Recently, some eclogites have been interpreted as residues from partial melting of oceanic crust to produce felsic magmas of tonalite-trondhjemite-granodiorite (TTG) composition (Ireland et al., 1994; Rudnick, 1995; Rollinson, 1997), which make up large portions of the crust in Archean cratons. If true, this has important implications: 1) subduction was operative in the Archean and 2) one reason the continental crust is more evolved than basalt is because Archean crustal growth was accomplished, at least in part, by direct addition of felsic magmas from the mantle.

Although the major and trace element data suggest a link between xenolithic eclogites and TTGs, no systematic study of these rocks from a single region has yet been performed in order to test this hypothesis.

We report here oxygen isotopic and trace element compositions of eclogite xenoliths from the Mesozoic Koidu kimberlite pipes located on the Man Shield of the West African Craton. The Man Shield is an ideal region to study the growth of Archean cratons for several reasons. First, extensive suites of eclogite xenoliths (Tompkins and Haggerty, 1984) and TTGs (Rollinson, 1978) have been collected from the same area. Second, previous petrological and mineral chemistry studies (Hills and Haggerty, 1989; Fung and Haggerty, 1995) provide an excellent starting point for trace element and isotopic investigations. Third, Koidu is one of few localities where whole rock data for major and trace elements are available for 25 eclogite xenoliths (Hills and Haggerty, 1989).

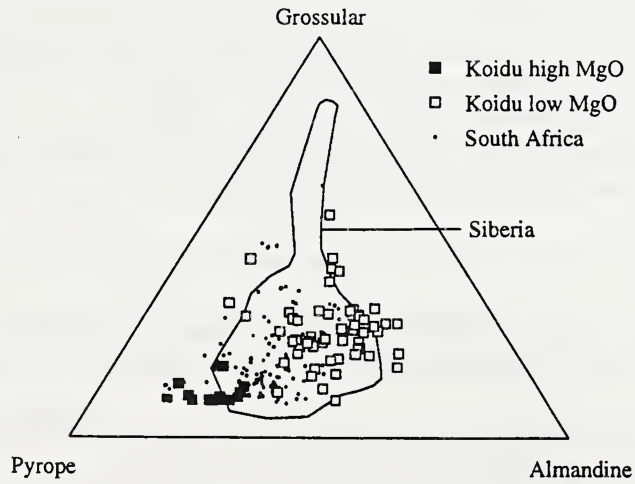

Fig. 1. Garnet compositions from Koidu eclogite xenoliths compared with those from other areas. The field encompasses data from Siberia. Diamondiferous eclogites are restricted to the low $\mathrm{MgO}$ group.

The Koidu eclogites fall into two groups, based on their major element chemistry: 1) A high $\mathrm{MgO}$ group ( $>16 \mathrm{wt} \% \mathrm{MgO}$ ) that is essentially bi-mineralic (garnet and omphacite), with only minor rutile, ilmenite, and/or sulfide. 2) A low $\mathrm{MgO}$ group (6-13 wt\% MgO), which commonly contains accessory phases such as kyanite, quartz (after coesite), graphite, diamond, amphibole, and/or corundum plus rutile, ilmenite, and sulfides in addition to garnet and omphacite. The difference in bulk composition is reflected in the garnet composition (Fig. 1). 


\section{Results}

Oxygen isotopic data were obtained from 17 clean garnet mineral separates by laser fluorination techniques (Valley et al., 1995). Garnet has been analyzed because it is the freshest

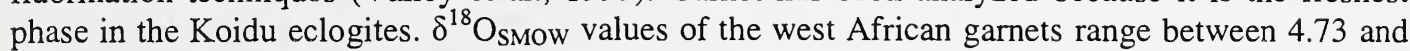
$6.09 \%$ (Fig. 2). Thus, neither very heavy nor very light values, as reported from South African eclogites (between 2.2 and 8.0\%o, MacGregor and Manton, 1986), are observed. The majority of the samples lie within the range of average mantle values (5.5 $\pm 0.4 \%$, Mattey et al., 1994). Calculated fractionation factors between garnet (gt) and clinopyroxene (cpx) are 0.2 to $0.3 \%$ (Rosenbaum et al., 1994), depending on equilibration temperature and composition of the sample. Therefore, the isotopic composition of gt is 0.1 to $0.15 \%$ o lighter than the bulk rock, assuming equal amounts of gt and cpx. If we apply this correction to our gt $\delta^{18} \mathrm{O}$ data, four samples exceed the mantle range, being both isotopically lighter and heavier (Fig. 2).

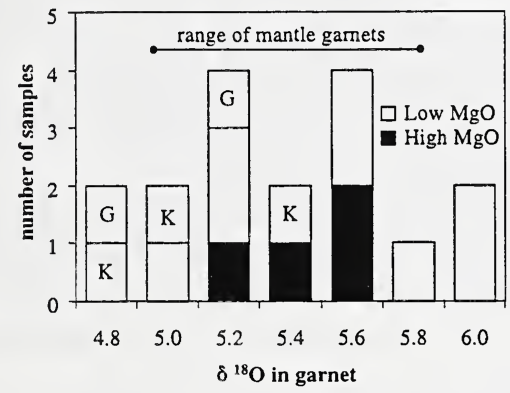

Fig. 2. $\delta^{18} \mathrm{O}_{\text {SMOW }}$ for Koidu garnets. The range of mantle garnets is shifted towards lighter isotopic composition by $0.1 \%$ relative to the whole rock mantle range due to the fractionation between garnet and whole rock. See text for details.

$\mathrm{G}=$ graphite-bearing low $\mathrm{MgO}$ eclogites

$\mathrm{K}=$ kyanite-bearing low $\mathrm{MgO}$ eclogites

The high $\mathrm{MgO}$ garnets have a restricted range of $\delta^{18} \mathrm{O}$ values (5.21 to 5.54\%o) and lie within average mantle values. The low $\mathrm{MgO}$ garnets have a broader range of isotopic and major element compositions. $\delta^{18} \mathrm{O}$ does not show a correlation with other elements (e.g., $\mathrm{FeO}, \mathrm{CaO}$ ) of garnet or whole rock, as reported for Siberian eclogite xenoliths (Jacob et al., 1994).

Whole rock trace element data were obtained by ICP-MS. All samples show variable degrees of enrichment in light rare earth elements (LREE, Fig. 3) and other highly incompatible elements due to kimberlite-related alteration. The degree of LREE enrichment correlates with the degree of alteration visible in thin section. Note that the freshest sample (KEC 81-5) exhibits depletion of middle REE relative to heavy REE.

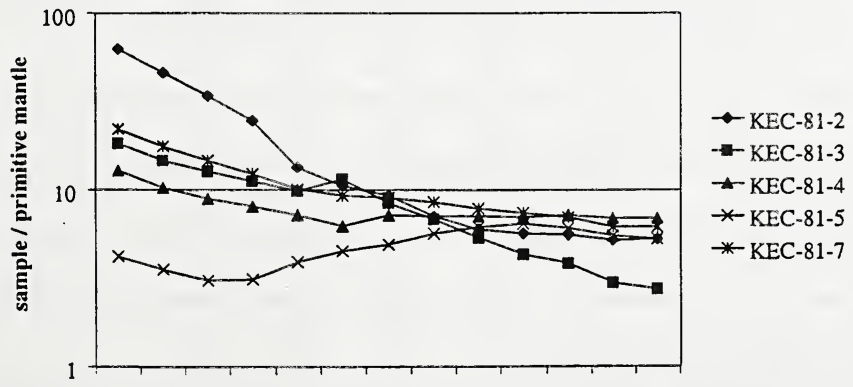

Fig. 3. Mantle-normalized whole rock REE data for Koidu eclogite xenoliths. Sample KEC 81-2 belongs to the high $\mathrm{MgO}$ group, all other samples belong to the low $\mathrm{MgO}$ group.

La Ce Pr Nd Sm Eu Gd Tb Dy Ho Er Yb Lu 


\section{Implications for the origin of eclogite xenoliths and Archean crustal growth}

The most compelling evidence for a crustal origin of eclogite xenoliths are stable isotope compositions that deviate from established peridotitic values, i.e., $\delta^{18} \mathrm{O}$ values that lie beyond $5.5 \pm 0.4 \%$ (e.g., MacGregor and Manton, 1986; Jacob et al., 1994). Eclogites with high and low $\delta^{18} \mathrm{O}$ values are believed to have obtained their isotopic compositions through low- and hightemperature seawater alteration prior to subduction.

The observed oxygen isotopes of the Koidu high $\mathrm{MgO}$ eclogites show mantle-like $\delta^{18} \mathrm{O}$, indicating either a mantle origin, hydrothermal alteration at intermediate temperatures, or a lack of hydrothermal alteration. The restricted range of compositions (Fig. 1) and high $\mathrm{MgO}, \mathrm{Ni}$ and $\mathrm{Cr}$ contents (Hills and Haggerty, 1989) support an intra-mantle origin for these samples.

In contrast, the broader range of $\delta^{18} \mathrm{O}$ of the low $\mathrm{MgO}$ eclogites suggests a crustal origin. In addition, the low $\mathrm{MgO}$ contents and the occurrence of kyanite in some eclogites put important constraints on possible petrogenetic models. Kyanite-bearing eclogites cannot coexist with peridotites at pressures in the diamond stability field, but would react with olivine to form pyroxenes and garnet. Thus, if the low $\mathrm{MgO}$ eclogites represent cumulates of fractionated highpressure mantle melts, it requires that these melts must have been kept isolated from the surrounding peridotite. However, these features can also be explained by metamorphism of mantlederived melts that crystallized at low pressure, i.e., by subduction of oceanic crust.

The Koidu low $\mathrm{MgO}$ eclogite major element compositions are similar to Archean greenstone belts and complementary to granitoids of the West African Craton (Rollinson, 1997), implying that the eclogites are residues from Archean granitoid crust formation. The high heavy REE content of the Koidu eclogites and the depletion of middle REE relative to heavy REE of sample KEC 81-5 support the model that melting of the mafic protolith occurred in the garnet stability field. In situ Laser ablation ICP-MS analyses of garnet and cpx are currently underway in order to define the preentrainment trace element composition of the eclogites.

\section{References}

Fung, A. T., and Haggerty, S. E., 1995, Petrography and mineral compositions of eclogites from the Koidu Kimberlite Complex, Sierra Leone: J. Geophys. Res., v. 100, p. 20,451-20,473.

Hills, D. V., and Haggerty, S. E., 1989, Petrochemistry of eclogites from the Koidu Kimberlite Complex, Sierra Leone: Contrib. Mineral. Petrol., v. 103, p. 397-422.

Ireland, T. R., Rudnick, R. L., and Spetsius, Z., 1994, Trace elements in diamond inclusions from eclogites reveal link to Archean granites: Earth Planet. Sci. Lett., v. 128, p. 199-213.

Jacob, D., Jagoutz, E., Lowry, D., Mattey, D., and Kudrjavtseva, G., 1994, Daimondiferous eclogites from Siberia: Remnants of Archean oceanic crust: Geochim. Cosmochim. Acta, v. 58, p. 5195-5207.

MacGregor, I. D., and Manton, W. I., 1986, Roberts Victor eclogites: ancient oceanic crust: J. Geophys. Res., v. 91, p. 14,063-14,079.

Mattey, D., Lowry, D., and Macpherson, C., 1994, Oxygen isotope composition of mantle peridotite: Earth Planet. Sci. Lett., v. 128, p. 231-241.

Rollinson, H. R., 1978, Zonation of supracrustal relics in the Archaean of Sierra Leone, Liberia, Guinea and Ivory Coast: Nature, v. 272, p. 440-442.

Rollinson, H., 1997, Eclogite xenoliths in west African kimberlites as residues from Archaean granitoid crust formation: Nature, v. 389, p. 173-176.

Rosenbaum, J. M., Mattey, D. P., and Elphick, S., 1994, Equilibrium garnet-calcite oxygen isotope fractionation: Mineral. Mag., v. 58A, p. 787-788.

Rudnick, R. L., 1995, Making continental crust: Nature, v. 378, p. 571-578.

Tompkins, L. A., and Haggerty, S. E., 1984, The Koidu Kimberlite Complex, Sierra Leone: Geological setting, petrology and mineral chemistry, in Kornprobst, J., ed., Kimberlites; I, Kimberlites and related rocks, 11A. Developments in Petrology: Amsterdam, Elsevier, p. 83-105.

Valley, J. W., Kitchen, N. E., Kohn, M. J., Niendorf, C. R., and Spicuzza, M. J., 1995, UWG-2, A garnet standard for oxygen isotope ratio: strategies for high precision and accuracy with Laser heating: Geochim. Cosmochim. Acta, v. 59, p. 5223-5231. 